\title{
Investigation of the Effect of $60 \%$ of the Addition of Latex on Asphalt Pen 60-70
}

\author{
Diana Alemin Barus ${ }^{1 *}$ and Supeto Nababan ${ }^{2}$ \\ ${ }^{1,2}$ Department of Physics, Faculty of Mathematics and Natural Science, Universitas Sumatera Utara \\ 20155, Indonesia
}

\begin{abstract}
This study discussed the increase of latex 60\% addition to obtain the standard of asphalt 60-70. The comparison used were without the increase of latex addition (L0), 1000 $\mathrm{g}$ penetration of asphalt 60-70 with $100 \mathrm{~g}$ latex with $60 \%$ degree or $10 \mathrm{phr}$ ( L1), $1000 \mathrm{~g}$ penetration of asphalt 60-70 with $200 \mathrm{~g}$ latex $60 \%$ degree or $20 \mathrm{phr}$ ( L2), $1000 \mathrm{~g}$ penetration of asphalt 60-70 with $300 \mathrm{~g}$ latex $60 \%$ degree or $30 \mathrm{phr}$ ( L3), $1000 \mathrm{~g}$ penetration of asphalt 60-70 with $400 \mathrm{~g}$ latex $60 \%$ degree or $40 \mathrm{phr}$ ( L4). All of the samples homogenized by heating at $150^{\circ} \mathrm{C}$ temperature and $250 \mathrm{rpm}$ within 30 minutes then soaked in the tub for 30 minutes at $25^{\circ} \mathrm{C}$.
\end{abstract}

Keyword: asphalt, latex, penetration.

Received 14 July 2020 | Revised [28 July 2020] | Accepted [27 August 2020]

\section{Introduction}

Indonesia has not been able to become the number one producer of natural rubber, because the productivity of rubber plantations in Indonesia is low, which is 1.19 tons/ha compared to Thailand of 1.7 tons/ha. The disposal of used tire waste into the environment can cause environmental pollution because the tire is not biodegradable in the soil and can cause disease. Because it is mixed in a hot state, it is often referred to as a hot mix that is done in a mixing plant called as Asphalt Mixing Plant (AMP). Lately asphalt research combined with materials such as rubber has been widely published and this pattern is very possible to make asphalt especially for highways in Indonesia. Long loading is a function of the thickness of pavement and speed of the vehicle [1]. Modified asphalt that has been sold in Indonesia since 1996 we know several brands, such as High Bonding Asphalt, Mexphalte, Cariphalt, Bituplus, Superfleks, Superphalt, Starbit, Aspal Prima 50, Retona, and so on [2].

Natural rubber particles contain rubber hydrocarbons and small amounts of non-rubber materials, such as fats, glycolipids, phospholipids, proteins, carbohydrates, inorganic materials, and others [3]. Considering that for the manufacture of car tires needed the best and most

*Corresponding author at: Jl. Bioteknologi No.1 Kampus USU, Medan, Indonesia, 20155

E-mail address: dianabarus@usu.ac.id 
expensive materials, this encourages entrepreneurs to use rubber. Latex Hevea consists of rubber, resin, protein, ash, sugar, and water [4]. The most commonly used method is the centrifugation method (sedation), since it produces a large production capacity, the latex viscosity is lower (not viscous), and the latex yield is purer (not mixed with sediment and dirt) [5]. The comparison between the amount of Nitrogen base and Acid Afit I with the amount of Acid Afit II and Paraffin is called the parameter of malten composition that determines the resistance of asphalt to abrasion [6]. Polymer styrene butadiene styrene (SBS) is a polymer that provides the most optimum combination of usable power, durability, ease of use and economy when compared to other synthetic elassers [7]. High ductility indicates that the asphalt is getting pliable, so the better it is used as a pavement binding material [8].

\section{Methods}

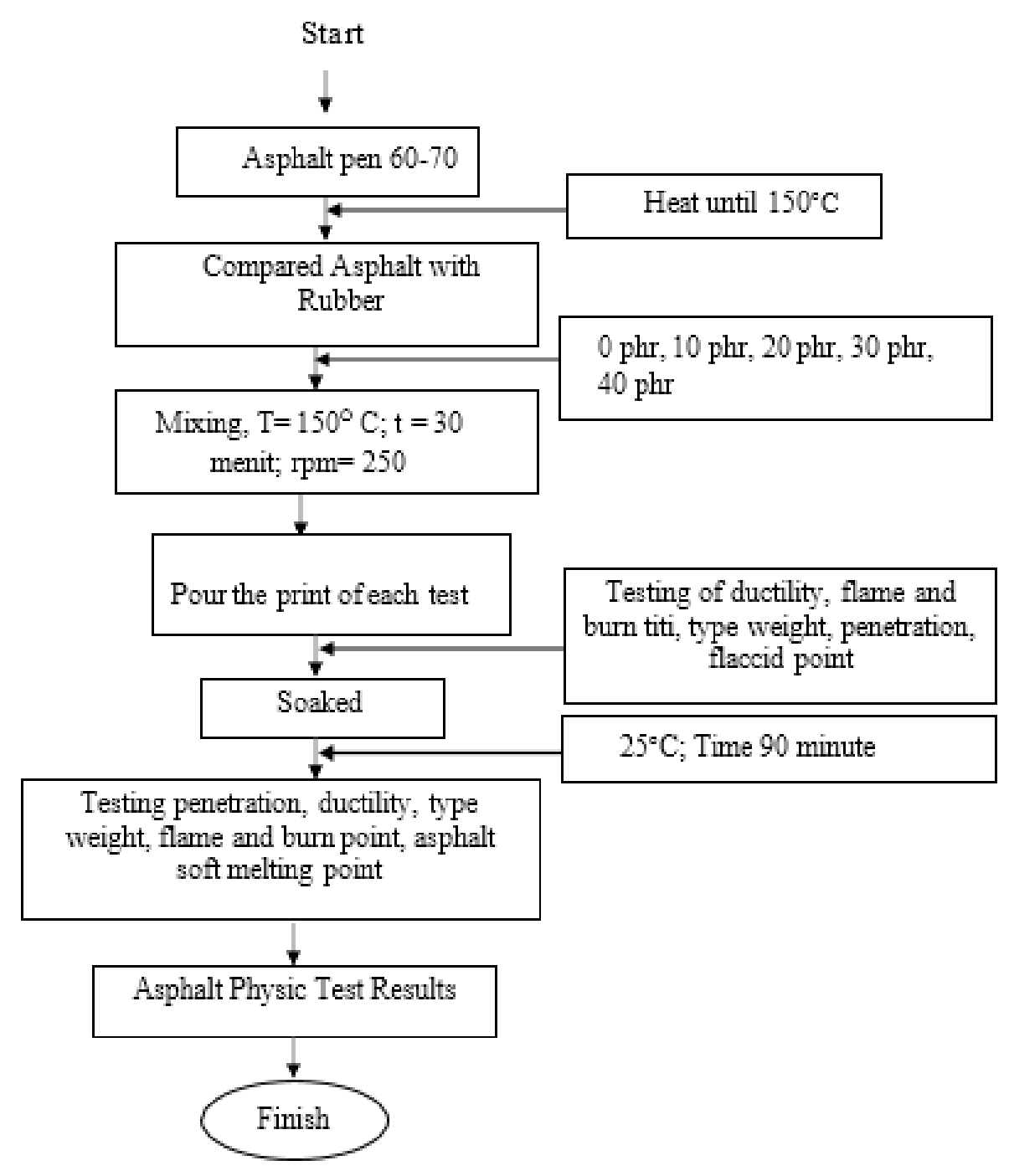

Figure 1. Research Flowchart 


\section{Result and Discussion}

\subsection{Latex Characteristics Yield $60 \%$}

Measurable ammonia content is $0.835 \%$. This concentrated latex is classified into high ammonia concentrated latex (high ammonia content) because it contains more than 0 ammonia. $6 \%$. The concentrated latex used in this study was concentrated latex with a dry rubber content of $58.4 \%$, meaning there were 58.4 grams of rubber particles in $100 \mathrm{~mL}$ of concentrated latex. The amount of concentrated latex solids used is $59.19 \%$, meaning there are 59.19 grams of total solids in $100 \mathrm{~mL}$ of concentrated latex. The difference between the value of the amount of solids and the content of dry rubber in concentrated latex is less than $2 \%$, which is $0.79 \%$, it indicates that concentrated latex contains non-rubber solids and dirtyers. The result of nitrogen level analysis is $0.24 \%$ [9]. From the analysis of nitrogen levels, it can be known the amount of protein contained in this concentrated latex. The type of hard asphalt is characterized by the penetration rate of asphalt, this figure states the hardness of the asphalt or the level of asphalt consistency [10]

\subsection{Latex Mixing Content of 60\% With Asphalt Pen 60-70}

Mixing latex into asphalt begins with asphalt heating at a temperature of $150-160 \mathrm{oC}$ at that temperature the asphalt melts perfectly [11]. The asphalt is heated or thawed on a container with an asphalt volume of $2 / 3$ the volume of the container. This aims to make room for the mixture to expand when latex is inserted into the hot asphalt [12].
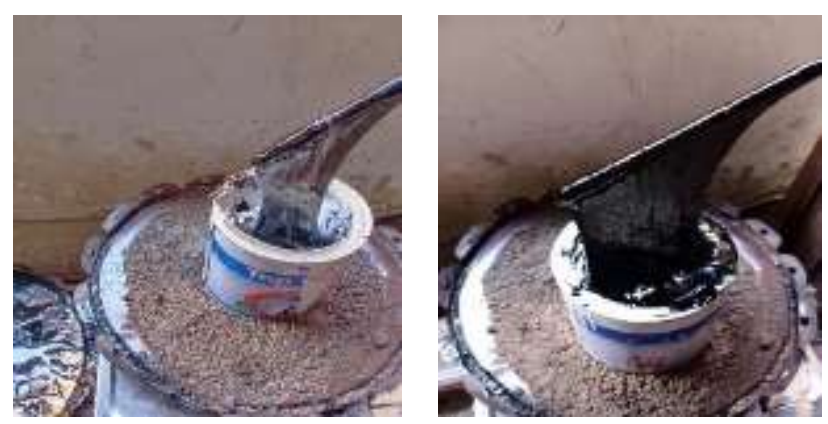

Figure 2 Rubber homogenization process with asphalt

\subsection{Latex Effect of $60 \%$ On Asphalt Penetration}

Table 1. Asphalt Pen Penetration test results 60-70 with Latex

\begin{tabular}{|c|c|c|}
\hline Sample & Latex Composition (\%) & Penetration $(\mathbf{m m})$ \\
\hline L0 & 0 & 60 \\
\hline L1 & 10 & 56 \\
\hline L2 & 20 & 65 \\
\hline L3 & 30 & 76 \\
\hline L4 & 40 & 86 \\
\hline
\end{tabular}


Table 1 shows that latex addition has a phr limit in order to obtain harder asphalt, while the addition of latex phr large enough to asphalt makes the penetration value increase, meaning the value of asphalt rigidity becomes decreased.

\subsection{Latex Effect Of 60\% On Asphalt Soft Spots}

Table 2. Test results Soft spot asphalt pen 60-70 with Latex

\begin{tabular}{|c|c|c|}
\hline Sample & Latex Composition (\%) & Soft Spot $\left({ }^{\mathbf{O}} \mathbf{C}\right)$ \\
\hline L0 & 0 & 50 \\
\hline L1 & 10 & 53 \\
\hline L2 & 20 & 53 \\
\hline L3 & 30 & 54 \\
\hline L4 & 40 & 57.5 \\
\hline
\end{tabular}

Table 2 shows the effect of latex addition with asphalt on soft spots, the higher the rubber content in the asphalt, the higher the mushy point value. This is because the higher the rubber content in the asphalt, the more rubber particles that fill the spaces between asphalt particles. Based on SNI 06-2434-1991 states that the minimum value of asphalt soft spots is $50^{\circ} \mathrm{C}$.

\subsection{Latex Effect of $60 \%$ On Asphalt Ductility}

Table 3. Test results of asphalt ductility pen 60-70 with Latex

\begin{tabular}{|c|c|c|}
\hline Sample & Latex Composition (\%) & Ductility $(\mathbf{c m})$ \\
\hline L0 & 0 & 100 \\
\hline L1 & 10 & 104 \\
\hline L2 & 20 & 150 \\
\hline L3 & 30 & 150 \\
\hline L4 & 40 & 125 \\
\hline
\end{tabular}

Table 3 shows the effect of latex addition with asphalt on the ductility of the increase in the value of asphalt ductility increased at $10 \mathrm{phr}, 20 \mathrm{phr}$ and $30 \mathrm{phr}$ while in $40 \mathrm{phr}$ there was a decrease in the value of ductility on asphalt. This is because the higher the rubber content in the asphalt, the more rubber particles that fill the spaces between asphalt particles.

\subsection{Latex Effect of $60 \%$ On Asphalt Flame and Burn Point}

Table 4. Test results Point on and burn asphalt pen 60-70 with Latex

\begin{tabular}{|c|c|c|c|}
\hline Sample & Latex Composition (\%) & Flash Point $\left({ }^{\mathbf{0}} \mathbf{C}\right)$ & Burn Point $\left({ }^{\mathbf{0}} \mathbf{C}\right)$ \\
\hline L0 & 0 & 200 & 235 \\
\hline L1 & 10 & 221 & 275 \\
\hline L2 & 20 & 255 & 283 \\
\hline L3 & 30 & 270 & 290 \\
\hline L4 & 40 & 280 & 305 \\
\hline
\end{tabular}

Table 4 shows the effect of rubber addition on flash points and burn points. The higher the rubber content in the asphalt, the higher the value of the flash point and the burn point. This 
happens because latex contains $40 \%$ water and other constituent components, so at the time of asphalt heating to find the point of flame and burn the asphalt occurs evaporation of water and other constituent components. When the phr is raised then the amount of water and other components in latex is also getting bigger .

\subsection{Latex Effect of 60\% On Asphalt Specific gravity}

Table 5. Test Results Specific gravity asphalt pen 60-70 with Latex

\begin{tabular}{|c|c|c|}
\hline Sample & Latex Composition $\mathbf{( \% )}$ & Specific gravity $\left(\mathbf{g}^{-m^{-1}}\right)$ \\
\hline L0 & 0 & 1.0246 \\
\hline L1 & 10 & 0.9317 \\
\hline L2 & 20 & 0.9129 \\
\hline L3 & 30 & 1.0613 \\
\hline L4 & 40 & 1.0472 \\
\hline
\end{tabular}

Table 5 shows the results of specific gravity test. in addition to $10 \mathrm{phr}$ shows a result of 0.9317 g. $\mathrm{ml}^{-1}$, for the addition of $20 \mathrm{phr}$ showed a result of 0.9129 g.ml ${ }^{-1}$, for the addition of $30 \mathrm{phr}$ showed a result of $1.0613 \mathrm{~g} \cdot \mathrm{ml}^{-1}$, for the addition of $40 \mathrm{phr}$ get a result of $1.0472 \mathrm{~g} . \mathrm{ml}^{-1}$, and for conventional asphalt get a result of 1 g.ml ${ }^{-1}$ [13]. In addition $10 \mathrm{phr}$ and $20 \mathrm{phr}$ get results smaller than 1 g.ml ${ }^{-1}$ according to SNI 06-2488-1991 does not qualify because it is below the standard value, while for $30 \mathrm{phr}$ and $40 \mathrm{phr}$ meets the standard based on the results of calculation of asphalt type weight because it has a value greater than 1 g.ml-1 [14].

\section{Conclusion}

Based on the phr used in asphalt mixture, latex utilization can be increased to $20 \mathrm{phr}$ while for $30 \mathrm{phr}$ or the rest only meet a few conditions in asphalt standards. The results of observation of asphalt pen characteristics 60-70 with the addition of latex content of $60 \%$ get the following conclusions, penetration results L0: $60 \mathrm{~mm}, \mathrm{~L} 1: 56 \mathrm{~mm}, \mathrm{~L} 2: 65 \mathrm{~mm}, \mathrm{~L} 3: 76 \mathrm{~mm}, \mathrm{~L} 4: 86 \mathrm{~mm}$. Soft spot results L0: $50^{\circ} \mathrm{C}, \mathrm{L} 1: 53^{\circ} \mathrm{C}, \mathrm{L} 2: 53^{\circ} \mathrm{C}, \mathrm{L} 3: 54^{\circ} \mathrm{C}, \mathrm{L} 4: 57.5^{\circ} \mathrm{C}$. The ductility of each sample was L0: $100 \mathrm{~cm}, \mathrm{~L} 1: 104 \mathrm{~cm}, \mathrm{~L} 2: 150 \mathrm{~cm}, \mathrm{~L} 3: 150 \mathrm{~cm}, \mathrm{~L} 4: 125 \mathrm{~cm}$. The result of the flash point was L0: $200^{\circ} \mathrm{C}, \mathrm{L} 1: 221^{\circ} \mathrm{C}, \mathrm{L} 2: 255^{\circ} \mathrm{C}, \mathrm{L} 3: 270^{\circ} \mathrm{C}, \mathrm{L} 4: 280^{\circ} \mathrm{C}$ and the burn result was L0: $235^{\circ} \mathrm{C}, \mathrm{L} 1: 275^{\circ} \mathrm{C}, \mathrm{L} 2: 285^{\circ} \mathrm{C}, \mathrm{L} 3: 290^{\circ} \mathrm{C}, \mathrm{L} 4: 305^{\circ} \mathrm{C}$. Result of ductility was L0: 1.0246 g.ml ${ }^{-1}, \mathrm{~L} 1: 0.9317$ g.ml ${ }^{-1}$, L2: 0.9129 g.ml ${ }^{-1}$, L3: 1.0613 g.ml ${ }^{-1}$, L4: 1.0472 g.ml ${ }^{-1}$.

\section{REFERENCES}

[1] Brown. S. F, An Introduction to The Analytical Design of Bituminous Pavement's, University of Nottingham, UK, 1984.

[2] Soehartono, Teknologi Aspal dan Penggunaannya. Andi Publisher, Jakarta, 2015.

[3] Tanaka. Y, A New Approach to Produce Highly Depot ei ni zed Natural Rubber, Kuliah Tamu Mengenai Karet Alam, BPTK Bogor, Bogor, 1998.

[4] Suparto. D, Pengetahuan Tentang Lateks Hevea, Kursus Teknologi Barang Jadi Lateks, 
Balai Penelitian Teknologi Karet Bogor, Bogor, 2002.

[5] Solichin, Karakteristik Beton Aspal Lapis Pengikat (AC-BC) yang Menggunakan Bahan Pengisi (Filler) Abu Sekam Padi, Texas Journal, vol. 15, no. 2, Palu, Jurusan Teknik Sipil Fakultas Teknik Universitas Tadulako, 2013.

[6] Suroso, Studi Sifat Reologi Aspal Yang Dimodifikasi Limbah Tas Plastik, Surabaya, Universitas Kristen Petra Surabaya, 2005.

[7] Robinson. H. L, Polymer in Asphalt, Rapra Review Reports, Vol. 15, No. 11, Tarmac Ltd, $\mathrm{UK}, 2004$.

[8] SNI 06-2433-1991, Metode Pengujian Titik Nyala Aspal Cair Dengan Alat Tag Open Cup, Badan Standardisasi Nasional.

[9] F. Denny, Pengaruh Bahan Tambah Limbah Logam Cor (Wojo) dan Filler Limbah Karbit pada Last on (AC-BC) Terhadap Karakteristik Marshall, Yogyakarta, UNY, 2018.

[10] AASHTO, Standard Specification on For Transport Action Materials and Method of Sampling and Testing, Part II, Specification 13 th British Standard, 1982.

[11] Ismardani, Karakteristik Beton Aspal Lapis Pengikat (AC- BC) yang Menggunakan Bahan Pengisi (Filler) Abu Sekam Padi, Texas Journal, vol 15, no. 2, Palu, Jurusan Teknik Sipil, Fakultas Teknik Universitas Tadulako, 2013.

[12] Direktorat Jenderal Bina Marga, Spesifikasi Umum Bidang Jalan dan Jembatan Tahun 2010 Revisi 3, Jakarta, Ditjen Bina Marga Kementerian PU, 2014.

[13] P. Rezza, Studi sifat reologi aspal yang dimodifikasi limbah tas plastik. Surabaya, Universitas Kristen Petra Surabaya, 2009.

[14] Fannisa. H, Wahyudi, M, Perencanaan Campuran Aspal Beton Dengan Menggunakan Filler Kapur Padam, Semarang, Program Studi Diploma III Teknik Sipil Fakultas Teknik Universitas Diponegoro, 2010. 